\title{
Clinical study of a method for the receptor apparatus of the teeth protection at the stages of treatment with non-removable prosthesis designs
}

\author{
0. V. Voznyi ${ }^{* 1, E, F}$, I. V. Yanishen ${ }^{2, A, C}$, I. L. Diudina ${ }^{2, A, B}$, V. H. Tomilinn ${ }^{2, B, E}$, A. V. Pohorila ${ }^{2, D, E}$
}

${ }^{1}$ Zaporizhzhia State Medical University, Ukraine, ${ }^{2}$ Kharkiv National Medical University, Ukraine

A - research concept and design; B - collection and/or assembly of data; C - data analysis and interpretation; D - writing the article;

$\mathrm{E}$ - critical revision of the article; $\mathrm{F}$ - final approval of the article

Key words: receptor apparatus, intact teeth, electroodontometry, mastication, protection technique, lightcuring adhesive, antihomotoxic drug.

Zaporozhye medical journal 2019; 21 (6), 790-794

DOl:

10.14739/2310-1210.

2019.6.186596

*E-mail:

aleksandrvoznyy.1965@

gmail.com
This article presents the results of clinical approbation of our proposed method for protecting the receptor apparatus of the teeth through a complex of domestic light-curing adhesive preparations and antihomotoxic drug "Traumeel", the application of which was substantiated by experimental studies in laboratory animals.

The purpose of the study was to confirm clinically the experimentally obtained results to protect the receptor apparatus of the teeth by using the antihomotoxic drug combined with the domestic light-curing adhesive.

Materials and methods. The method was tested in 72 patients, of whom 57 were the main group and 15 were controls. They were divided into 3 subgroups by age. A total of 200 teeth were prepared for one-piece cast fixed implant-supported prostheses. Electro-odontometry (EO) was performed and masticatory force (MF) was measured by the proposed method (patent number 99095142 dated September 16, 1999) before the preparation, when an anesthetic was worn off and one month after preparation.

Results. The positive results of our method were clinically confirmed by the EO data analysis and the MF values measured by proposed by us method on the day of the study, the next day, in a month after the intact teeth were coated with the proposed complex of preparations. When assessing the data obtained, it was found that there were no significant changes in the EO indices as well as MF indicators on the day of the examination, the next day, in a month after the examination in the study group compared with the control.

Conclusions. Analyzing the results obtained, it can be noted that our method has a significant advantage in protecting the stumps during teeth preparation at the stages of treatment with non-removable prosthesis design and contributes to preventing complications of the hard dental tissue preparation.
Ключові слова: рецепторний апарат,

інтактні зуби, електроодонтометрія, жування, методика захисту, світлотверАний алгезив, антигомотоксичний препарат.

Запорізький медичний

журнал. - 2019. -

T. 21, № 6(117). -

C. $790-794$

\section{Киінічне випробування методу захисту рецепторного апарату зубів на етапах Аікування незнімними конструкціями протезів}

\section{О. В. Возний, І. В. Янішен, І. А. АюАіна, В. Г. Томікін, А. В. Погоріла}

Мета роботи - клінічне підтвердження експериментально отриманих результатів щодо захисту рецепторів жувального тиску зубів шляхом застосування антигомотоксичного препарату разом з вітчизняним світлотвердним адгезивом.

Матеріали та методи. Метод апробований на 72 пацієнтах, з них 57 утворили основну, а 15 - контрольну групу, яких поділили на 3 підгрупи за віковими ознаками. Препарували під опорні елементи незнімних суцільнолитих протезів 200 зубів. Вимірювали показники електроодонтометрії (ЕО) та жувального тиску (ЖТ), застосовуючи метод, який запропонували (патент № 99095142 від 16.09.1999), до операції препарування, після завершення дії анестезії та через місяць після препарування.

Результати. Позитивні результати розробленого методу в клініці підтверджуються аналізом даних електроодонтометрії та значення жувального тиску, що виміряли за методикою, яку запропонували, в день дослідження, наступного дня, через місяць і через рік після того, як інтактні зуби були покриті комплексом препаратів за допомогою методу, який запропонували. Оцінюючи результати, встановили: в основній групі порівняно з контрольною показники електроодонтометрії в день дослідження, через день, через місяць після дослідження не мали значущих змін, те саме стосується показників жувального тиску в названих періодах дослідження.

Висновки. Аналізуючи отримані результати, визначили, що метод має суттєву перевагу щодо захисту кукси під час підготовки інтактних зубів на етапах лікування незнімними конструкціями протезів і сприяє запобіганню ускладнень операції з підготовки твердих тканин.

\section{Клиническое испытание метода защиты рецепторного аппарата зубов на этапах лечения несъемными конструкциями протезов}

\section{А. В. Возный, И. В. Янишен, И. А. Аюдина, В. Г. Томияин, А. В. Погорелая}

Цель работы - клиническое подтверждение экспериментально полученных результатов по защите рецепторов жевательного давления зубов путем применения антигомотоксического препарата с отечественным светоотверждаемым адгезивом. 
Материалы и методы. Метод апробирован на 72 пациентах, из которых 57 составляли основную, а 15 - контрольную группу, которых разделили на 3 подгруппы по возрастным признакам. Препарировали под опорные элементы несъемных цельнолитых протезов 200 зубов. Измеряли показатели электроодонтометрии (ЭО) и жевательного давления (ЖТ) предложенным ранее методом (патент № 99095142 от 16.09.1999), до операции препарирования, после окончания действия анестезии и через месяц после препарирования.

Результаты. Положительные результаты разработанного метода в клинике подтверждаются анализом данных электроодонтометрии и значений жевательного давления, измеренных по предложенному методу, в день исследования, на следующий день, через месяц после того, как интактные зубы были покрыты комплексом препаратов предлагаемым методом. При оценке полученных данных установлено, что в основной группе по сравнению с контрольной по показателям электроодонтометрии в день исследования, через день, через месяц и год после исследования значимых изменений показателей не было, то же относится к данным жевательного давления в указанные периоды исследования.

Выводы. Анализируя полученные результаты, установлено, что предложенный метод обладает существенным преимуществом защиты культи при подготовке интактных зубов на этапах обработки несъемными конструкциями протезов и способствует профилактике осложнений операции по подготовке твердых тканей.

At present, the most commonly used prosthesis constructions are plastic- or ceramic-coated one-piece-cast, but the number of cases involving intact tooth pulp extraction, which is considerably supportive, regardless of an initial state of the tooth, has significantly increased in fixing these dentures. The reason for this is the desire of orthopedic dentists to avoid possible complications in the hard dental tissue preparation linked to the data about possible damage to the dentinal tubules and, as a result, the disturbance of hydrodynamic odontoblast processes. Depending on the removed layer of dentin, there is also a possibility to start compensatory mechanisms. However, it depends on the volume of tissues prepared, time interval since intervention $[1,2,6,9,10,11,14]$.

Nevertheless, these protective reactions do not always start. Therefore, the first stage of prosthetic preparation is a dental pulp extraction. But some researches have proven that this manipulation significantly reduces the strength of dentin, which is the reason of frequent damage to the tooth crown after prosthetic treatment and a decrease in toughness and resistance to MF during functional loading $[3,5,7,8,12]$.

To preserve intact teeth and prevent negative consequences, various methods of pulp extraction and techniques for preservation of supporting pulp vitality and reduction of their sensitivity after preparation were proposed by many scientists. According to these methods, the stumps of the prepared teeth were covered with various materials, provisional crowns, which were fixed with one-step and multi-step self-etching adhesives. However, none of the proposed methods resulted in restoration of the dental hard tissue and odontoblast processes damage during preparation, which are a part of the mechanoreceptors in the tooth pulp $[4,13,15]$.

In view of the above and taking into account the relevance and practical importance of this issue, we proposed a method that was tested in the clinical practice of orthopedic dentistry.

\section{Purpose}

The purpose of the study was to confirm clinically the experimentally obtained results to protect the receptor apparatus of the teeth by using the complex of antihomotoxic drug "Traumeel" and the domestic light-curing adhesive.

\section{Materials and methods}

The method was tested in 72 patients, 57 of whom were the main group and 15 were controls. They were divided into 3 subgroups by age. In total, 200 teeth were prepared for one-piece cast fixed implant-supported prostheses. The dental stump was prepared according to our method consisting of the following steps: an infiltration anesthesia giving preference to intraligamentary injections using anesthetics of the articaine formulations such as Septanest, Ultracain with 1:100.000 or 1:200.000 epinephrine depending on the clinical case.

The dental hard tissues were ground with a centered and sharp water-cooled abrasive tool at 300.000 revolutions per second. After preparation, the stumps of the teeth were covered with etching gel for $20-30$ seconds. This significantly contributes to medicines penetration into the dential tubules. Then the gel was washed away by a water stream, sterile cotton pellet was placed to isolate the stump of the tooth and absorb any oral fluids and, if necessary, a saliva aspirator was used additionally, the stumps were dried with warm air. The antihomotoxic drug "Traumeel" was applied evenly over the dental stump surface with an applicator and a current of warm air. The domestic light-curing adhesive was subsequently applied with the applicator over the antihomotoxic preparation. The current of warm air was used to remove the rest of the drug. Following that, the adhesive was polymerized for 20 seconds. To reduce the environmental effect on the dental stumps of the prepared tooth, temporary crowns that were point-ofcare made before the dental preparation, were fixed with the water dentine via material of GNJ Tempo Lux Company according to the standard methods $[10,11]$.

For clinical validation of the experimental study results, the parameters of EO and MF were measured according to the method proposed by us (patent No. 99095142 of 16.09.1999) before the preparation, when an anesthetic was worn off and one month after the preparation.

\section{Results}

The data analysis was aimed at determining the dynamics of EO and MF indicators, naturally occurring after the dental hard tissues preparation, the effectiveness of our proposed methodology in the experimental and control groups of patients as well as identifying the factors contributing to positive and, possibly, negative changes. ANOVA was used to measure statistical differences between results
Киючевые слова: рецепторный аппарат, интактные зубы, электроодонтометрия, жевание, методика защиты, светоотверждаемый аАгезив, антигомотоксический препарат.

Запорожский медицинский журнал. - 2019. T. 21, № 6(117). C. $790-794$ 


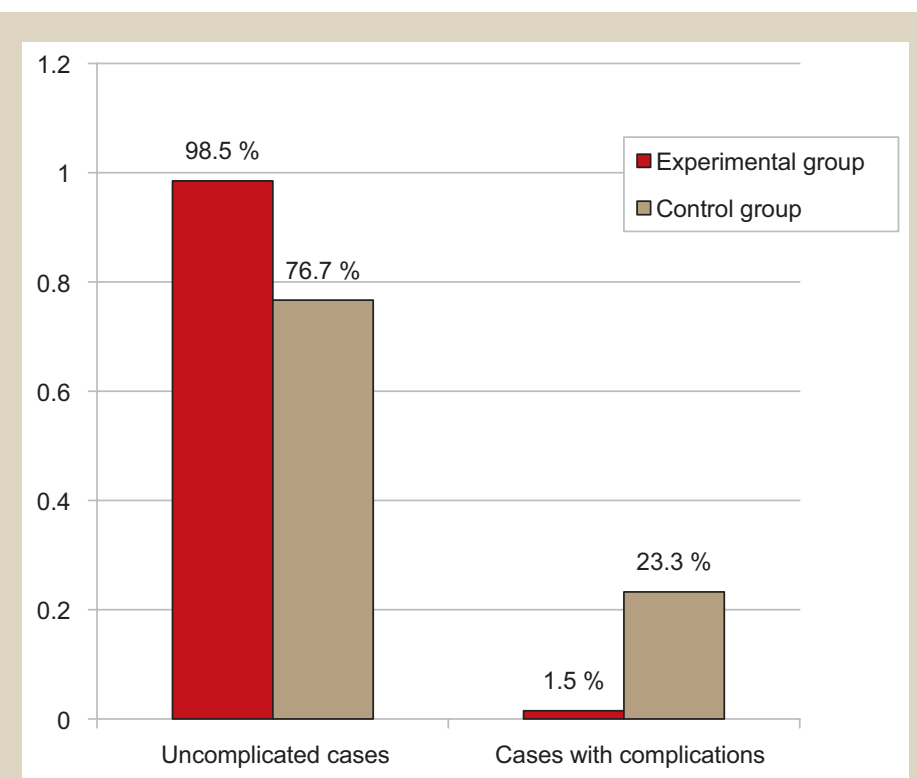

Fig. 1. Percentage of uncomplicated and complicated cases by electro-odontometry after teeth preparation in the studied and control groups.

of the analysis using SAS software package. Regression analysis was implemented using Statistica software package (StatSoft Inc., № JPZ804I382130ARCN10-J).

As shown in Table 1, the EO parameters remained practically unchanged or slightly increased in the study group before the operation of preparation, on the next day and in a month after that when using our method, and did not depend on the group of teeth.

The EO values showed almost the same downward trend, except for incisors, after the preparation in both the study and control group.
However, the picture was significantly changed in a month. If the EO indicators remained the same as they were before the preparation for the studied group, a statistically significant increase in these indices was observed in the control group concerning practically all anatomically oriented teeth, except for canines.

Looking at the average EO values in the study group, it can be seen that indicators were not increased in $84.96 \%$ of cases after the experimental processing of the teeth. In $13.54 \%$ of cases, there was a slight increase in this indicator and only in $1.5 \%$ of cases it was increased, that can be interpreted as a complication.

In the controls, unlike the study group, the EO index was not increased only in $20 \%$ of cases, and it was significantly increased in $23.3 \%$ of cases that can be interpreted as a complication, but a change in the indices was of 1-2 units from baseline in $56.7 \%$ of cases. It is notable that the control group indicators were more than 2 times higher than in the study group. This indicates a much less certainty regarding the control processing results.

There were only 2 cases with complications in the study group constituting $1.5 \%$ of the total number of teeth processed by our method. At the same time, there were 14 complicated cases in the control group accounting for $23.3 \%$ of the studied teeth number (Fig. 1).

The average values (M) of the MF and the standard errors of the mean (m), obtained from the clinical study, by patient groups and anatomically oriented groups of teeth are given in Table 2 .

The analysis of MF measurements (Table 2) demonstrated independence of these indicators from the group of teeth and absence of their significant changes in the studied individuals.

The MF data from Table 2 shows that the increase in this index was statistically significant for not only the incisors

Table 1. Indicators of electro-odontometry, MA

\begin{tabular}{|c|c|c|c|c|c|c|c|c|c|c|c|c|c|}
\hline \multirow[t]{2}{*}{ Group } & \multirow[t]{2}{*}{ Index } & \multicolumn{3}{|l|}{ Incisors } & \multicolumn{3}{|l|}{ Canines } & \multicolumn{3}{|l|}{ Premolars } & \multicolumn{3}{|l|}{ Molars } \\
\hline & & Before & $\begin{array}{l}\text { On the } \\
\text { next day }\end{array}$ & $\begin{array}{l}\text { In } \\
\text { a month }\end{array}$ & Before & $\begin{array}{l}\text { On the } \\
\text { next day }\end{array}$ & $\begin{array}{l}\text { In } \\
\text { a month }\end{array}$ & Before & $\begin{array}{l}\text { On the } \\
\text { next day }\end{array}$ & \begin{tabular}{|l|} 
In a \\
month
\end{tabular} & Before & $\begin{array}{l}\text { On the } \\
\text { next day }\end{array}$ & $\begin{array}{l}\text { In } \\
\text { a month }\end{array}$ \\
\hline \multirow[t]{3}{*}{ Study } & M & 3.24 & 2.21 & 3.34 & 4.10 & 2.85 & 3.95 & 4.36 & 3.06 & 4.42 & 5.20 & 3.74 & 5.65 \\
\hline & M & 0.09 & 0.09 & 0.15 & 0.23 & 0.21 & 0.25 & 0.15 & 0.12 & 0.14 & 0.16 & 0.18 & 0.24 \\
\hline & & $\mathrm{P} 1<0.00$ & & $\mathrm{P} 2>0.05$ & $\mathrm{P} 1<0.001$ & & $\mathrm{P} 2>0.05$ & $\mathrm{P} 1<0.001$ & & $P 2>0.05$ & $\mathrm{P} 1<0.001$ & & $\mathrm{P} 2>0.05$ \\
\hline \multirow[t]{3}{*}{ Control } & M & 3.22 & 2.67 & 6.22 & 4.75 & 3.50 & 5.25 & 4.20 & 2.93 & 6.07 & 4.83 & 3.89 & 6.89 \\
\hline & M & 0.15 & 0.24 & 0.76 & 0.48 & 0.50 & 0.48 & 0.20 & 0.16 & 0.36 & 0.22 & 0.14 & 0.62 \\
\hline & & $\mathrm{P} 1<0.05$ & & $\mathrm{P} 2<0.001$ & $\mathrm{P} 1<0.001$ & & $\mathrm{P} 2<0.001$ & $\mathrm{P} 1<0.001$ & & $\mathrm{P} 2<0.001$ & $\mathrm{P} 1<0.05$ & & $\mathrm{P} 2<0.001$ \\
\hline
\end{tabular}

P1: significance between before the preparation and on the next day after that; P2: significance between before the preparation and in a month after that.

Table 2. Masticatory force indicators, $\mathrm{pF}$

\begin{tabular}{|c|c|c|c|c|c|c|c|c|c|c|c|c|c|}
\hline \multirow[t]{2}{*}{ Group } & \multirow[t]{2}{*}{ Index } & \multicolumn{3}{|l|}{ Incisors } & \multicolumn{3}{|l|}{ Canines } & \multicolumn{3}{|l|}{ Premolar } & \multicolumn{3}{|l|}{ Molar } \\
\hline & & Before & $\begin{array}{l}\text { On the } \\
\text { next day }\end{array}$ & $\begin{array}{l}\text { In } \\
\text { a month }\end{array}$ & Before & $\begin{array}{l}\text { On the } \\
\text { next day }\end{array}$ & $\begin{array}{l}\text { In } \\
\text { a month }\end{array}$ & Before & $\begin{array}{l}\text { On the } \\
\text { next day }\end{array}$ & \begin{tabular}{|l|} 
In \\
a month
\end{tabular} & Before & \begin{tabular}{|l|} 
On the \\
next day
\end{tabular} & \begin{tabular}{|l|} 
In \\
a month
\end{tabular} \\
\hline \multirow[t]{3}{*}{ Study } & M & 10.79 & 12.79 & 11.41 & 14.10 & 16.15 & 14.40 & 18.44 & 20.53 & 19.00 & 31.66 & 33.97 & 32.63 \\
\hline & M & 0.23 & 0.26 & 0.40 & 0.46 & 0.47 & 0.47 & 0.39 & 0.39 & 0.38 & 0.59 & 0.57 & 0.61 \\
\hline & & $P<0.001$ & & $P>0.05$ & $P<0.001$ & & $P>0.05$ & $P<0.001$ & & $P>0.05$ & $P<0.01$ & & $P>0.05$ \\
\hline \multirow[t]{3}{*}{ K } & M & 10.22 & 12.55 & 13.44 & 15.00 & 17.55 & 16.75 & 18.89 & 21.83 & 22.00 & 33.00 & 35.67 & 36.27 \\
\hline & M & 0.60 & 0.63 & 0.69 & 0.71 & 0.75 & 1.11 & 0.35 & 0.36 & 0.40 & 0.46 & 0.47 & 0.65 \\
\hline & & $P<0.01$ & & $P<0.01$ & $P<0.05$ & & $P<0.05$ & $P<0.001$ & & $P<0.001$ & $P<0.001$ & & $P<0.001$ \\
\hline
\end{tabular}

P1: significance between before the preparation and on the next day after that; P2: significance between before the preparation and in a month after that. 
and canines on the next day after processing if compared between the study and control groups, as this increase concerning the premolars and molars was significantly greater in the control group than in the experimental group.

The MF indicators of the experimental group were not increased in $55.64 \%$ of cases in a month after processing. In $42.1 \%$ of cases, this indicator was increased of $1-2 \mathrm{pF}$ and only in $2.26 \%$ of cases - of $4 \mathrm{pF}$ and more that can be understood as complications.

In the control group, the MF indicator was not increased only in $3.33 \%$ of cases and its significant increase (4 pF and more) was observed in $36.66 \%$ of cases that could be considered as complications (Fig. 2).

\section{Discussion}

From the analysis of the obtained results, it can be seen that the $E O$ and MF indicators remained at the same level in a month after preparation in more than $50 \%$ of the cases and did not depend on the tooth anatomical orientation in those patients who underwent the proposed by us protective method of stumps supporting during teeth preparation [12]. Nevertheless, in the control group, where our technique was not applied, the same indicators were significantly increased in a month and the anatomical dependence of the tooth was very important. The largest increase in these indicators was observed for incisors, then for canines, premolars and less for all the molars.

\section{Conclusions}

Thereby, we can see a significant advantage of our method in protecting the intact stumps during teeth preparation at the stages of treatment with non-removable prosthesis design. This makes it possible to apply our protective method of stumps supporting in the wide orthopedic practice and significantly increase the use of orthopedic non-removable denture helping prevention of complications in the hard dental tissues preparation.

Conflicts of interest: authors have no conflict of interest to declare. Конфлікт інтересів: віАсутній.

Надійшла Ао редакції / Received: 14.05.2019

Після Аоопрацювання / Revised: 16.08.2019

Прийнято Ао Аруку / Accepted: 10.09.2019

Information about authors:

Voznyi O. V., MD, PhD, DSc, Associate Professor, Head of the Department of Therapeutic, Prosthetic and Pediatric Dentistry, Zaporizhzhia State Medical University, Ukraine. Yanishen I. V., MD, PhD, DSc, Professor, Head of the Department of Orthopedic Dentistry, Kharkiv National Medical University, Ukraine.

Diudina I. L., MD, PhD, Associate Professor, Department of Orthopedic Dentistry, Kharkiv National Medical University, Ukraine.

Tomilin V. H., MD, PhD, Associate Professor, Department of Orthopedic Dentistry, Kharkiv National Medical University, Ukraine.

Pohorila A. V., MD, Assistant, Department of Orthopedic Dentistry, Kharkiv National Medical University, Ukraine.

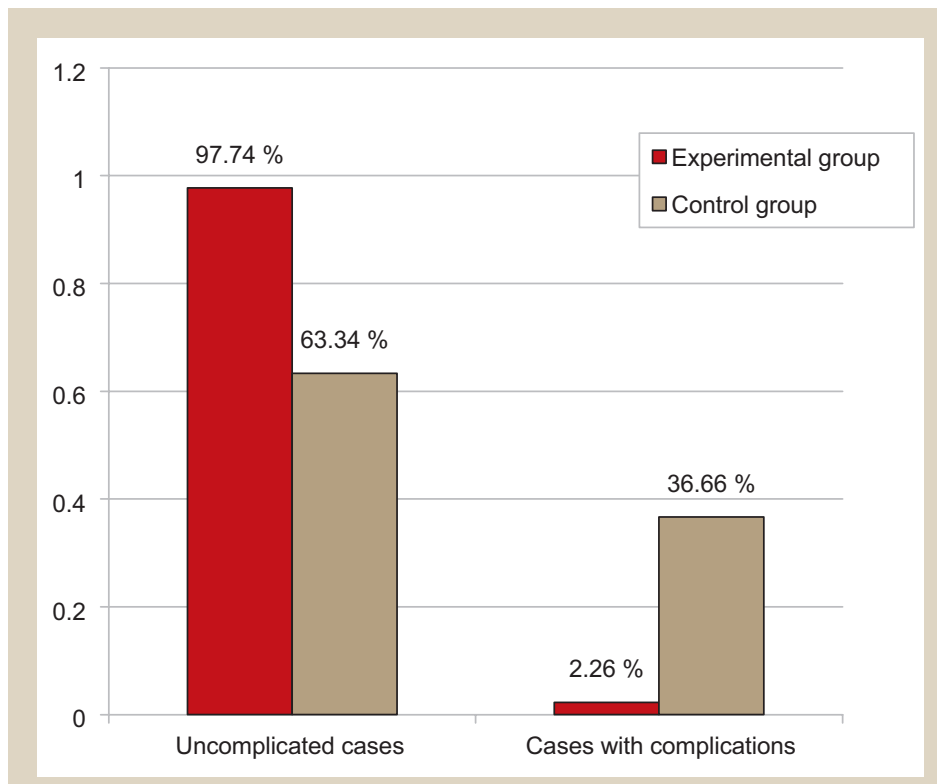

Fig. 2. Percentage of uncomplicated and complicated cases by MF indicator after teeth preparation in the studied and control groups.

Відомості про авторів:

Возний О. В., А-р меА. наук, Аоцент, зав. каф. терапевтичної, ортопедичної та Аитячої стоматології, Запорізький Аержавний медичний університет, Україна.

Янішен I. В., А-р меА. наук, професор, зав. каф. ортопедичної стоматології, Харківський національний медичний університет, Україна.

АюАіна І. ^., канА. меА. наук, Аоцент каф. ортопедичної стоматології, Харківський національний медичний університет, Україна.

Томілін В. Г., канА. меА. наук, Аоцент каф. ортопедичної стоматології, Харківський національний медичний університет, україна.

Погоріла А. В., асистент каф. ортопедичної стоматології, Харківський національний меАичний університет,

Україна.

\section{Сведения об авторах:}

Возный А. В., А-р меА. наук, Аоцент, зав. каф. терапевтической, ортопедической и Аетской стоматологии, Запорожский государственный медицинский университет, Украина.

Янишен И. В., А-р меА. наук, профессор, зав. каф. ортопедической стоматологии, Харьковский национальный медицинский университет, Украина. Аюдина И. ^., канА. меА. наук, Аоцент каф. ортопедической стоматологии, Харьковский национальный меАицинский университет, Украина.

Томилин В. Г., канА. меА. наук, доцент каф. ортопедической стоматологии, Харьковский национальный медицинский университет, Украина.

Погорелая А. В., ассистент каф. ортопедической стоматологии, Харьковский национальный меАицинский университет, Украина.

\section{References}

[1] Bolshakov, G. V., \& Bedjurova, B. K. (2002). Izuchenie temperaturnoj chuvstvitelnosti zubov na jetapah ortopedicheskogo lechenija [Study of the temperature sensitivity of teeth during the orthopedic treatment]. Institute of Dentistry, 1, 30-31. [in Russian].

[2] Bolshakov, G. V., \& Kuznecov, O. S. (2009). Germetizacija vskrytyh dentinnyh kanalcev posle odontopreparirovanija [Sealing of opened dentinal tubules after odontodissection]. Current issues in dentistry. Collection of Scientific Abstracts. (S. 45-47). Moscow. [in Russian]. 
[3] Makeeva, I. M., Panina, T. M., Amanatidi, G. E., \& Pogabalo, I. V. (2002). Issledovanie reakcii sosudov pulpy na primenenie razlichnyh adgezivnyh sistem [Study of the reaction of pulp vessels to the use of various adhesive systems]. Stomatology, 6, 20-23. [in Russian].

[4] Garazha, S. N., Grishilova, E. N., Kashnikov, P. A., Garazha, I. S., \& Kodzhakova, T. Sh. (2013). Morfologicheskie izmenenija v povrezhdennom dentine zubov pod vlijaniem sinteticheskogo gidroksiapatita [Morphology of damage due dentin of the teeth synthetic hydroxyapatite]. Fundamental research, 9(6), 999-1002. [in Russian].

[5] Kalamkarov, H. A. (2003). Ortopedicheskoe lechenie s primeneniem metallokeramicheskih protezov [Orthopedic treatment with metal-ceramic prostheses]. Moscow. [in Russian].

[6] Petrikas, A. Zh., Petrikas, O. A., Kartoshkin, A. A., \& Zhuravlev, O. N. (2018). Pulpotomija pri protezirovanii zubov. Pilotnoe issledovanie [Pulpotomiya at prosthetics of teeth. Pilot research]. Actual problems in dentistry, 14(2), 48-51. [in Russian].

[7] Gente, M. (2001). Novyj metod ogranichenija glubiny preparirovanija [A new method for limiting the dissection depth]. NewDent, 2, 38-45. [in Russian].

[8] Zabuha, Yu. I., \& Bida, O. V. (2016). Rezultaty ortopedychnoho likuvannia patsiientiv $z$ defektamy tverdykh tkanyn vitalnykh zubiv [The results of orthopedic treatment of patients with defects of hard tissues of vital teeth]. Ukrainian Dental Almanac, 2, 40-42. [in Ukrainian].

[9] Bida, V. I., Struk, V. I., Bida, O. V., \& Sydorenko, T. H. (2015). Pokaznyky mikrotsyrkuliatsii tkanyn parodonta u osib z patolohichnym styranniam tverdykh tkanyn zubiv riznoho stupenia tiazhkosti, uskladnenym bruksyzmom [Indicators of microcirculation in periodontal tissues in individuals with pathological abrasion of hard tissues of teeth of varying severity, complications of bruxism]. Collected Works employees NMAPO them. PLShupyk, 24(1), 471-477. [in Ukrainian].

[10] Yanishen, I. V., \& Diudina, I. L. (2016). Patohenetychni mekhanizmy rozvytku zmin u retseptornomu aparati zubiv pid chas preparuvannia tverdykh tkanyn ta vplyv depulpuvannia na yikh vytryvalist do mekhanichnykh navantazhen (ohliad literatury) [Pathogenetic mechanism of development of change in reception apparatus of teeth in during preparation hard tissues and impact the devitalization on fixedness to mechanical load (review of the literature)]. Journal of Medical and Biological Problems, 1(126), 62-66. [in Ukrainian].

[11] Holik, V. P., \& Diudina, I. L. (2013). Vplyv operatsii preparuvannia tverdykh tkanyn na pulpu zuba pid chas likuvannia neznimnymy konstruktsiiamy proteziv [Influence the operation of preparation hard tissue on pulp of tooth in period] Treatment by Fixed Dental Prosthesis, 1(4), 11-15. [in Ukrainian]

[12] Abdollahi, A., \& Jalalian, E. (2019). Effectiveness of two desensitizer materials, potassium nitrate and fluoride varnish in relieving hypersensitivity after crown preparation. The Journal of Contemporary Dental Practice, 20(4), 489-493.

[13] Nawareg, M. M., Zidan, A. Z., Zhou, J., Chiba, A., Tagami, J., \& Pashley, D. H. (2015). Adhesive sealing of dentin surfaces in vitro: A review. American journal of dentistry, 28(6), 321-332.

[14] Dereiko, L. V., Zhyznomyrska, O. O., Samoiliuk, L. H., Trukh, H. H., \& Nefodova, T. O. (2005). Zastosuvannia antyhomotoksychnoi terapii v kompleksnomu likuvanni heneralizovanoho parodontytu [The importance of antihomotoxic therapy for generalized parodontitis combined treatment]. Medicine of Ukrainian transport, 3, 63-65. [in Ukrainian]

[15] Yanishen, I., Diudina, I., Krychka, N., Diieva, T., \& Kuznetsov, R. (2019). Experimental justification of a method-of-choice to protect the receptor apparatus of the teeth, supporting a non-removable design denture. Georgian Medical News, 1(286), 36-39. 